\title{
Engasjement mot atomvåpen
}

\author{
Atomvåpnene truer liv og helse. Atommaktene rår over mer enn 20000 atomstridshoder, mange utplassert \\ rundt om i verden og i u-båter, nok til å tilintetgjøre alt liv på jorden - flere ganger. Det er viktigere enn noen- \\ sinne å engasjere seg i arbeidet mot atomvåpen.
}

Atomvåpen er noe vi helst ikke vil tenke på. Men i april 2009 holdt president Obama en tale i Praha der han uttrykte troen på det mange mener er umulig - nemlig en verden fri for atomvåpen. Det bidro sterkt til at han fikk Nobels fredspris samme år. Mange varog er - kritiske, særlig fordi det mangler en konkret tiltaksplan og et tidsperspektiv. Det har allikevel skjedd en holdningsendring mot vektlegging av de humanitære aspekter ved atomtrusselen. Sluttdokumentet fra tilsynskonferansen for ikke-spredningsavtalen «uttrykker den dypeste bekymring for de katastrofale humanitære konsekvensene av enhver bruk av atomvåpen, og stadfester nødvendigheten av at alle stater til alle tider etterlever gjeldende internasjonal rett, inkludert internasjonal humanitær rett» (1). Russland og USA har også ratifisert en ny START-avtale (Strategic Arms Reduction Treaty) som forplikter partene til å redusere antall atomstridshoder.

Selv om mange opplever at det etter fredsprisen har skjedd lite på det politiske plan når det gjelder atomnedrustning $o g$ at blant annet rakettskjoldplanene har avsporet nedrustningsprosessen, er det desto viktigere at sivilsamfunnet engasjerer seg. Det er mulig å få politikere til å handle når de har en sterk opinion og viktige organisasjoner i ryggen. Konvensjonene mot landminer og klasevåpen er bevis på det og viser at Norge kan spille en viktig rolle. Disse konvensjonene viser også hvilken betydning de norske humanitære organisasjoner har. I tråd med den humanitære katastrofetrusselen atombomber representerer, har president Kellenberger i Den internasjonale Røde Kors-komiteen (ICRC) tatt til orde for å forby atomvåpen på rent humanitært grunnlag. Et slikt engasjement fra Røde Kors er svært viktig. Vi skal også huske at Haag-domstolen i 1996 stemplet atomvåpen som ulovlige stridsmidler og i strid med internasjonal humanitær rett, som blant annet uttrykker at partene i en konflikt alltid skal skille mellom sivilbefolkningen og de stridende parter. Angrep skal utelukkende rettes mot militære mål (2).

\section{ICAN - internasjonal kampanje for avskaffelse av atomvåpen}

De tre organisasjonene Nei til atomvåpen, Norske leger mot atomvåpen og Den Norske Pugwashkomité (Pugwash er en internasjonal organisasjon av vitenskapsfolk mot atomvåpen) har i flere år hatt et nært samarbeid. I 2006 organiserte disse tre forenin-

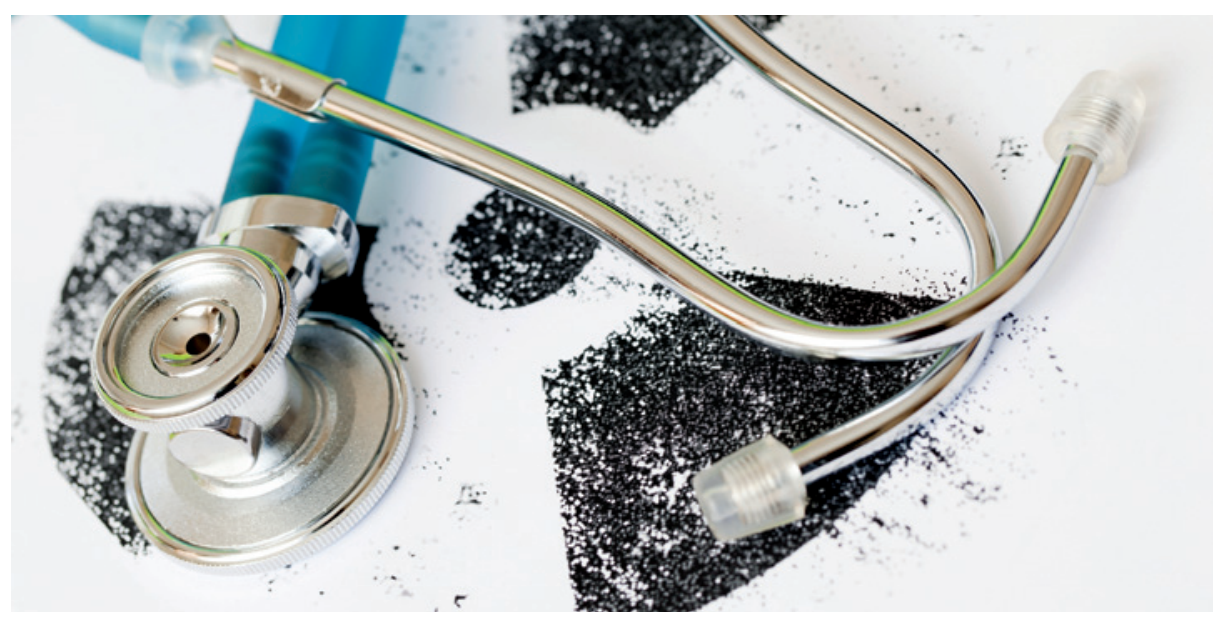

Illustrasjon Istockphoto

gene en underskriftskampanje til støtte for en konvensjon mot atomvåpen som samlet ca. 25000 underskrifter. Året etter, i 2007, ble det etablert en internasjonal organisasjon: ICAN (International Campaign to Abolish Nuclear Weapons) (3). Den norske avdelingen, ICAN Norge (4), ble opprettet i 2010 med de tre organisasjonene som faddere. Denne satsingen har vært mulig fordi Utenriksdepartementet i Norge har gitt støtte til driften av både det norske og det internasjonale sekretariatet for ICAN.

Arbeidet gjennom ICAN, nasjonalt og internasjonalt, vil utvilsomt bli en viktig del av Norske leger mot atomvåpens virksomhet framover. For å skape det momentum som er nødvendig i dette - $\mathrm{i}$ videste forstand - forebyggende helsearbeidet trenger vi et vedvarende engasjement fra medisinstudenter, leger og annet helsepersonell. Vi kan ikke gi oss før det internasjonale samfunn har lyktes $i$ å etablere forpliktende avtaler som eliminerer alle atomvåpen $\mathrm{i}$ en storstilt «avrustningsindustri» under internasjonal kontroll.

\section{Medisinsk fredsarbeid}

For helsepersonell som ønsker å lære mer, finnes det tilbud om nettkurs i medisinsk fredsarbeid (5). Kurset er organisert av et europeisk nettverk av fredsorganisasjoner og undervisningsinstitusjoner, der også Legeforeningen og Senter for internasjonal helse ved Universitetet i Bergen har bidratt. I 2010-11 er dette europeiske initiativet forankret og administrert av helseavdelingen hos Fylkesmannen i Troms, med assisterende fylkeslege Klaus Melf som kontaktperson (6).

$\mathrm{Vi}$ håper norske leger fortsatt ønsker å bruke tid og ressurser på arbeidet for en tryggere verden uten atomvåpen. Lykkes vi, kan vi få positive ringvirkninger på mange andre områder - blant annet sterkere vektlegging av generell fattigdom og uhelse.

\section{Hans Asbjørn Holm \\ asbjholm@online.no \\ Gamle Hovsetervei 2D}

Oslo

\section{Kirsten Osen}

Luftfartsveien 10

Oslo

Hans Asbjørn Holm (f. 1941) er lege og styremedlem i Norske leger mot atomvåpen (NLA). Ingen oppgitte interessekonflikter.

Kirsten Osen (f. 1928) er lege og rådsmedlem i Norske leger mot atomvåpen (NLA). Ingen oppgitte interessekonflikter.

Litteratur

1. Final Documents of the 2010 Review Conference, Vol.1, Part 1. www.un.org/en/conf/npt/2010 (22.9.2011)

2. Genèvekonvensjonene. Tilleggsprotokoll I, artikkel 48.

3. International Campaign to Abolish Nuclear Weapons. www.icanw.org (22.9.2011)

ICAN Norge. www icanw no (22.9.2011).

5. Medical Peace Work. www. medicalpeacework.org (22.9.2011).

6. Medisinsk fredsarbeid. www.helsetilsynet.no/ upload/Publikasjoner/helsesosialmelding/ troms helse omsorgsmelding2010.pdf (22.9.2011). 